\title{
Environmental implications of end pit lakes at oil sand mines in Alberta, Canada
}

1 Louis K. Kabwe PhD

Research Associate, Department of Civil and Environmental Engineering, University of Alberta, Edmonton, AB, Canada (corresponding author: Ikabwe@ualberta.ca)

2 J. Don Scott PhD, FEIC, PEng

Professor Emeritus, Department of Civil and Environmental Engineering, University of Alberta, Edmonton, $A B$, Canada
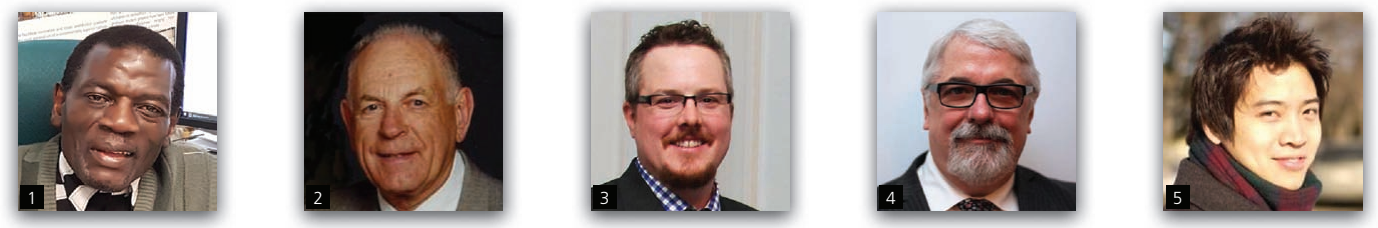

End pit lakes are common at open-pit metal mines around the world and are part of mine closure plans. Those at oil sand mines are no different except that the end pit lakes will be considerably larger, with the area averaging about $4 \mathrm{~km}^{2}$ and reaching up to about $15 \mathrm{~km}^{2}$. In a major study on end pit lakes for oil sand mines, the Cumulative Environmental Management Association defines an oil sand end pit lake as 'an engineered water body, located below grade in an oil sands post-mining pit'. It may contain oil sand by-product material and will receive surface and groundwater from surrounding reclaimed and undisturbed landscapes. End pit lakes will be permanent features in the final reclaimed landscape, discharging water to the downstream environment. As a permanent feature, the longterm environmental effect of such an oil sand deposit must be carefully designed and monitored. If the end pit lake contains an appreciable thickness of tailings, the consolidation of tailings may continue for many decades. The effects of groundwater leakage are analysed and modelled to show the potentially large amounts of seepage into the underlying stratigraphic units.

\section{The oil sands of Alberta}

Oil sands are located in three major areas in north-east Alberta underlying $140200 \mathrm{~km}^{2}$. Alberta has proven oil reserves of 170 billion barrels, consisting of bitumen (about 168 billion barrels) and conventional crude oil ( 1.7 billion barrels). These oil reserves are the third largest in the world, exceeded only by those in Venezuela and Saudi Arabia. Alberta's oil sands produce about 1.9 million barrels of oil per day, providing about $55 \%$ of all Canadian crude production. Only $3 \%$ of the total oil sands' surface area can be surface mined; however, $20 \%$ of the oil sand reserves are in this area. Extraction of the bitumen is done by surface mining or by in situ methods, depending on the proximity of the resource to the surface. Surface mining extracts deposits with less than $75 \mathrm{~m}$ of overburden, whereas in situ methods extract deeper underground deposits. Oil sand ore is a natural mixture of sand, water, clay and a type of heavy oil called bitumen. Bitumen must be removed from the sand and water before being upgraded into crude oil and other petroleum products. In surface mining operations, shovels extract the sand ore and trucks move it to an extraction facility (Alberta Government, 2015a).

As of July 2013, there were 114 active oil sand projects in Alberta. Of these, six were producing mining projects (three more are under application); the remaining projects use various in situ recovery methods (Alberta Government, 2015a). The Alberta Energy Regulator (AER) ensures that appropriate precautions are taken to develop oil sand resources in the interests of all Canadians. This happens through regulation, review of applications, management of conditions and approvals, surveillance and enforcement. Before any mining project begins, the industry must develop and receive approval for closure plans that outline how affected areas will be reclaimed. Mine operators must also provide reclamation security as a guarantee that reclamation work will take place (Alberta Government, 2015a). As of 30 June 2013, the Alberta government held over $\$ 1$ billion in reclamation security for the oil sand industry. The objective of this paper is to examine one closure option planned by all surface mines: the development and operation of end pit lakes (EPLs). The specific objective is to evaluate the upper range for the bottom seepage flux from EPLs for an extreme set of boundary conditions. This does not include evaluating quality issues for surface water and groundwaters. Modelling of fine oil sand tailings at the bottom of EPLs indicates that the fine tailings will tend to seal the bottom. Although the bottom seepage flux becomes small, given the large area of the EPLs, it may amount to a substantial volume. 
Environmental Geotechnics

Volume 6 Issue EG2
Environmental implications of end pit

lakes at oil sand mines in Alberta, Canada

Kabwe, Scott, Beier, Wilson and Jeeravipoolvarn

\section{End pit lakes}

EPLs are common at open-pit mines around the world. Precious metal mines, iron mines, coal mines and uranium mines have EPLs as part of their mine closure plans. Usually these EPLs are not large, with an area less than $1.9 \mathrm{~km}^{2}$. The Cumulative Environmental Management Association (CEMA, 2012a) EPL document provides direction on the closure of oil sand mine pits and the development of EPLs based on the experience of other surface mining industries. It reviews the nature and distribution of non-oil sand pit lakes, with a special emphasis on existing northern latitude (i.e. above $40^{\circ}$ north) pit lakes in North America. These lakes are exposed to similar climate conditions which are expected to influence the behaviour of future oil sand EPLs, namely, equivalent solar radiation, winter ice cover and spring ice melt. In addition, these lakes have developed under similar regulatory requirements and public expectations as future oil sand EPLs in Alberta.

Usually EPLs for metal mines are not large, having an area of about $0.01-1.9 \mathrm{~km}^{2}$ and being very deep. Coal mine EPLs, however, are more similar to the proposed EPLs for the oil sand mines, and the Alberta coal mine EPLs provide good examples, being about $6-55 \mathrm{~m}$ deep. Oil sand mines are different with their EPLs being considerably larger, their area averaging $4 \mathrm{~km}^{2}$ and reaching up to about $15 \mathrm{~km}^{2}$. In a major study on EPLs for oil sand mines, CEMA (2012b: p. 17) defines an oil sand EPL as 'an engineered water body, located below grade in an oil sands postmining pit. It may contain oil sands by-product material and will receive surface and groundwater from surrounding reclaimed and undisturbed landscapes. EPLs will be permanent features in the final reclaimed landscape, discharging water to the downstream environment'.

Alberta's Ministry of Sustainable Resource Development stated the following objective: ' $\ldots$ end pit lakes have to be designed to fit the future landscape (whatever that may be) and to be a surface feature that can be used by the general public and any other land users, in a safe and appropriate (as specified by policy) manner. It must meet short-term, medium-term, and long-term water quality objectives to support fish populations, wildlife and migratory or seasonable waterfowl use, human use, and must meet recreational water quality guidelines' (CEMA, 2012b: p. 49).

In addition, provisions for reclamation set out in Alberta's Environmental Protection and Enhancement Act (2000) require reclaiming disturbed lands to a state of equivalent land capability (i.e. similar to but not necessarily identical to what existed prior to mining). It is proposed that EPLs can meet this objective while providing permanent containment of fine tailings solids under a freshwater cap. This proposal was approved by the Alberta Energy and Utilities Board (now the AER), subject to industry demonstration. The permanent placement of fine tailings solids in EPLs is approved for many oil sand mines, subject to demonstration. This demonstration has not been completed yet, but is in progress at the Syncrude oil sand mine site.
The CEMA (2012b) EPL guidance document provides the locations of the planned EPLs in the oil sand mining area. According to Burkus et al. (2014), there are 32 EPLs presently planned for the oil sand mining area. Only eight of these will contain fluid fine tailings or mature fine tailings (MFTs) capped with fresh water; the others will contain oil sand tailings pond water capped with fresh water (Burkus et al., 2014). As discussed later, the presence of MFTs has a beneficial effect because when they consolidate, they aid in sealing the bottom of the EPL from bottom leakage. However, MFTs also have detrimental effects due to the long time these may take to consolidate during which these may release tailings water, bitumen and/or gas into the freshwater cap. A typical EPL is depicted in Figure 1 (CEMA 2012c) after it is filled. This sketch is for a small EPL. The area for most oil sand EPLs will be much larger, and therefore, the possibility of bottom leakage will be much larger, which is discussed in the following sections.

\section{EPL issues}

There are several key issues with EPLs that must be understood and resolved before the industry can demonstrate that EPLs will be successful and perform as planned (Westcott, 2007). Two physical issues of importance not originally included by Westcott (2007) include bottom leakage and gas release. This paper will concentrate on the topic of bottom leakage with some general references on gas release. The other issues including groundwater quality are beyond the scope of this paper, and interested readers can find useful related information in the publications of Bill (2014) and Gibson et al. (2013).

CEMA (2012b: p. 28) also lists key design elements: 'An EPL design is ultimately constrained by the mining configuration and the characteristics of the ore body deposit. As a result, many of the key design elements of an EPL are decided early on in the planning process, such as location, geometry, and lake content. Landform designers and reclamation planners will have the greatest influence on the design during the initial planning stages. Among the design parameters that must be considered are: Hydraulic residence time, Lake area, depth, and shape, Orientation to prevailing winds, Shoreline complexity, Lake filling time, Water sources for lake

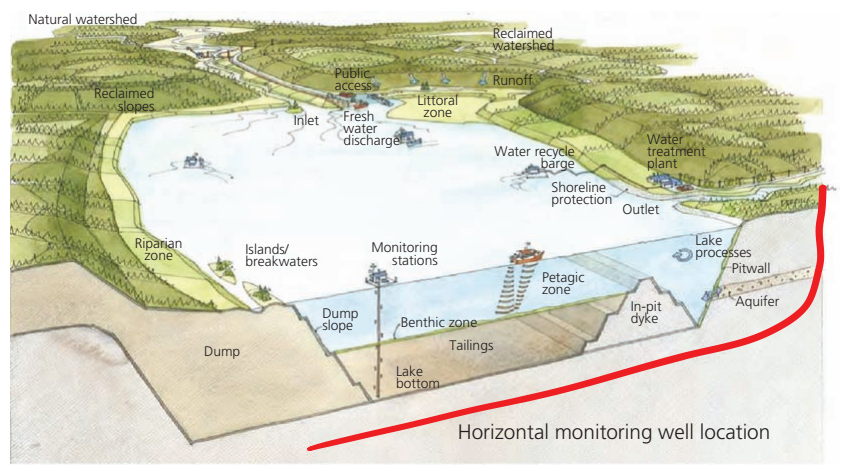

Figure 1. A cross-section of an end pit lake (EPL) depicting monitoring stations (after CEMA (2012c)) 
Environmental implications of end pit

lakes at oil sand mines in Alberta, Canada

Kabwe, Scott, Beier, Wilson and Jeeravipoolvarn filling, Salinity, process-water parameters and organics, Hydrologic sustainability (integration with surface water and groundwater), Habitat features, Human and wildlife access and Climate change'.

\section{Bottom seepage}

\section{Basal geology}

Seepage of the contained tailings water through the bottom of an EPL into the groundwater regime and eventually into surface waters is controlled by many factors with the underlying geology being a main influence. The stratigraphic column in the Athabasca oil sands area is shown in Figure 2 (CEMA, 2012b). The stratigraphy below the McMurray Formation down to the Precambrian rocks is what will underlay the oil sand EPLs. These formations are not continuous in the oil sand surface mining area, and the underlying geology will change for different EPLs and even under a large area EPL. The hydrostratigraphic units of the formations are of particular interest. The formations listed as aquifer systems are permeable formations which can conduct leakage water vertically and horizontally. The aquiclude systems are low-permeability formations which contain leakage if they are not fractured.

Figure 3 (CEMA, 2012d) is a sketch showing the typical stratigraphy underlying an oil sand EPL. Permeable strata such as $K_{\mathrm{m}}$ water sands, $D_{\mathrm{w}}$ limestone and $D_{\mathrm{m}}$ evaporites provide seepage paths to groundwater units and surface water bodies. Since groundwater flows at small velocities, it can take decades for groundwater pollutants to migrate from a source to a receptor. This reality means that groundwater monitoring will likely be necessary for years or decades after specific operations cease, particularly if the specific source of contaminants is still present and keeps releasing contaminants to the underlying stratigraphy (i.e. process water leaking from an EPL).

\section{Prairie Evaporite}

The northern one-third of the Athabasca oil sand deposit overlies a segment of a $150 \mathrm{~km}$ wide Middle Devonian Prairie Evaporite salt dissolution trend that extends for $1000 \mathrm{~km}$ along the eastern up-dip margin of the Middle Devonian Elk Point evaporite basin (Figure 4) (Broughton, 2013). More than $100 \mathrm{~m}$ of salt removal with only $200 \mathrm{~m}$ of overlying strata created sharply defined collapse structures at a scale unlike any elsewhere. Since a thick halite salt karst is prone to very rapid dissolution collapse, this has resulted in trends with relatively cataclysmic collapse-subsidence. The removal of such anomalously thick halite salt layers in the very shallow subsurface has resulted in pronounced karst features such as sinkholes, erosional tunnels and fractures which provide a ready path for groundwater movement.

Sinkhole sags (Figure 5) (Broughton, 2013) are observed cutting the entire lower McMurray interval attached to underlying Devonian fault blocks or breccia pipes. These $20-25 \mathrm{~m}$ dia. structures have been uncovered during oil sand mining operations in the Aurora and Muskeg Rivers along the central Bitumont trough. These structures usually extend vertically to the top of the lower McMurray interval and provide vertical channels for groundwater migration.

\section{Bottom seepage amounts}

The approvals for tailings ponds by the AER require that operators report on the seepage of tailings release water into groundwater or

\begin{tabular}{|c|c|c|c|c|c|c|c|c|}
\hline Era & \multicolumn{2}{|c|}{ Period } & Group & Formation & Member & Lithologic description & \multicolumn{2}{|c|}{ Regional hydrostratigraphic units } \\
\hline \multirow{2}{*}{ Cenozoic } & \multicolumn{5}{|c|}{ Holocene } & Muskeg/organic soils, alluvium & \multirow{3}{*}{\multicolumn{2}{|c|}{$\begin{array}{l}\text { Quaternary quifer and } \\
\text { aquitard system }\end{array}$}} \\
\hline & \multicolumn{5}{|c|}{ Pleistocene } & Sand, gravel, silt, clay, till & & \\
\hline \multirow{8}{*}{ 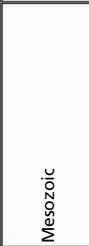 } & \multicolumn{6}{|c|}{ Erosional unconformity (major gap in geologic sequence) } & & \\
\hline & \multirow{6}{*}{ 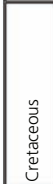 } & \multirow{6}{*}{$\sum_{0}^{0}$} & \multirow{6}{*}{ 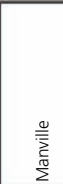 } & \multicolumn{2}{|l|}{ Grand rapids $\left(K_{q}\right)$} & Lithic sand and sandstone & \multirow{6}{*}{$K$ to $Q$} & \multirow{2}{*}{\begin{tabular}{|l|} 
Grand Rapids aquifer \\
Clearwater aquitard \\
\end{tabular}} \\
\hline & & & & \multirow{2}{*}{ Clearwater $\left(K_{c}\right)$} & & Lower and upper estuarine sand, silt and clay & & \\
\hline & & & & & Wabiskaw $\left(K_{\text {cw }}\right)$ & Glauconitic sandstone & & Wabiskaw aquifer \\
\hline & & & & \multirow{3}{*}{ McMurray $\left(K_{\mathrm{m}}\right)$} & Upper & Marine sand, silt and clay & & \multirow{3}{*}{$\begin{array}{l}\text { McMurray aquifer/aquitard } \\
\text { system }\end{array}$} \\
\hline & & & & & Middle & Lower and upper estuarine sand, silt and clay & & \\
\hline & & & & & Lower & Continental fluvial sand, floodplain and lagoon clay & & \\
\hline & \multicolumn{6}{|c|}{ Erosional unconformity (major gap in geologic sequence) } & & \multirow{7}{*}{$\begin{array}{l}\text { Beaverhill Lake } \\
\text { aquifer system }\end{array}$} \\
\hline \multirow{15}{*}{ 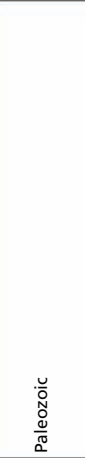 } & \multirow{14}{*}{ 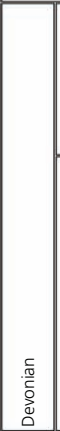 } & \multirow{5}{*}{ 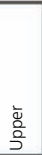 } & \multirow{8}{*}{ 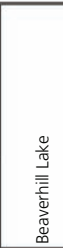 } & \multirow{4}{*}{ Waterways $\left(D_{\mathrm{w}}\right)$} & Moberly & \multirow{4}{*}{$\begin{array}{l}\text { Alternating sequence of argillaceous limestone, } \\
\text { calcareous shale and clastic limestone }\end{array}$} & \multirow{5}{*}{ |D2 } & \\
\hline & & & & & Christina & & & \\
\hline & & & & & Calumet & & & \\
\hline & & & & & Firebag & & & \\
\hline & & & & \multicolumn{2}{|l|}{ Paraconformity } & & & \\
\hline & & \multirow{9}{*}{$\frac{\frac{0}{0}}{\frac{0}{2}}$} & & Slave Point & & Dolomitic limestone & \multirow{10}{*}{ D1 } & \\
\hline & & & & \multirow{2}{*}{\multicolumn{2}{|c|}{\begin{tabular}{|l} 
Paraconformity \\
\end{tabular}}} & & & \multirow{5}{*}{$\begin{array}{l}\text { Prairie-Watt Mountain } \\
\text { aquiclude system }\end{array}$} \\
\hline & & & & & & Anhydrite and dolomite & & \\
\hline & & & & Watt Mountain & & Shale, siltstone and anhydrite & & \\
\hline & & & & Muskeg & & Anhydrite and dolomite & & \\
\hline & & & & Prairie Evaporite & & Salt and anhydrite & & \\
\hline & & & & Methy & & Reefal dolomite & & Methy-McClean aquifer- \\
\hline & & & 흥 & McClean River & & Dolomite, claystone and evaporite & & aquitard system \\
\hline & & & 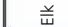 & La Loche & & Claystone and arkosic sandstone & & Basal aquifer \\
\hline & Erosior & al unc & onformity & ajor gap in geoloc & sequence) & & & \\
\hline Proterozoic & Precan & brian & & & & Metasedimentary rocks and granite & & Aquiclude \\
\hline
\end{tabular}

Figure 2. Stratigraphic column for the Athabasca oil sands region (CEMA (2012b)) 
Environmental implications of end pit

lakes at oil sand mines in Alberta, Canada

Kabwe, Scott, Beier, Wilson and Jeeravipoolvarn

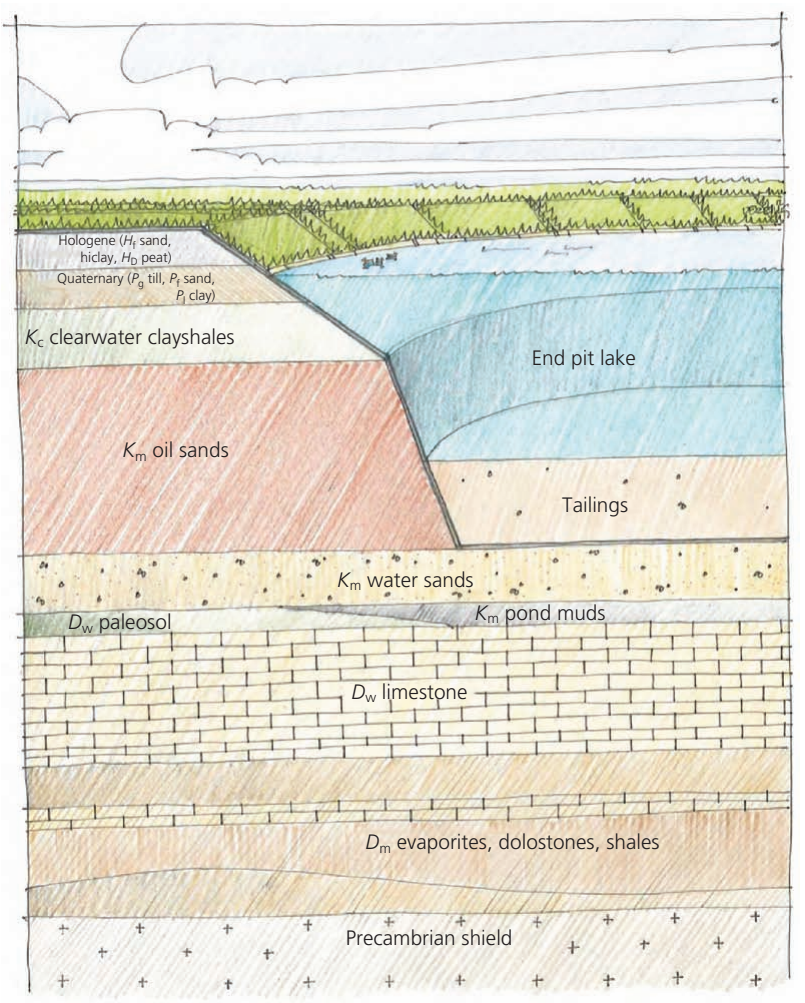

Figure 3. Representative stratigraphy underlying an oil sands EPL (after CEMA (2012d)). $D_{m}$, Prairie evaporite; $D_{w}$, Devonian waterways formation; $H_{D}$, holocene Devonian; $H_{f}$, holocene fluvial; $K_{\mathrm{m}}$, McMurray formation oil sands; $P_{\mathrm{f}}$, glaciolacustrine fluvial; $P_{\mathrm{g}}$, glacial till; $P_{\mathrm{l}}$, glaciolacustrine clay

surface water. The group Environmental Defence has compiled tailings seepage rates based on publicly available data on oil sand mine applications (Environmental Defence, 2008). They discovered that as of 2007 , the total volume of tailings process-affected water
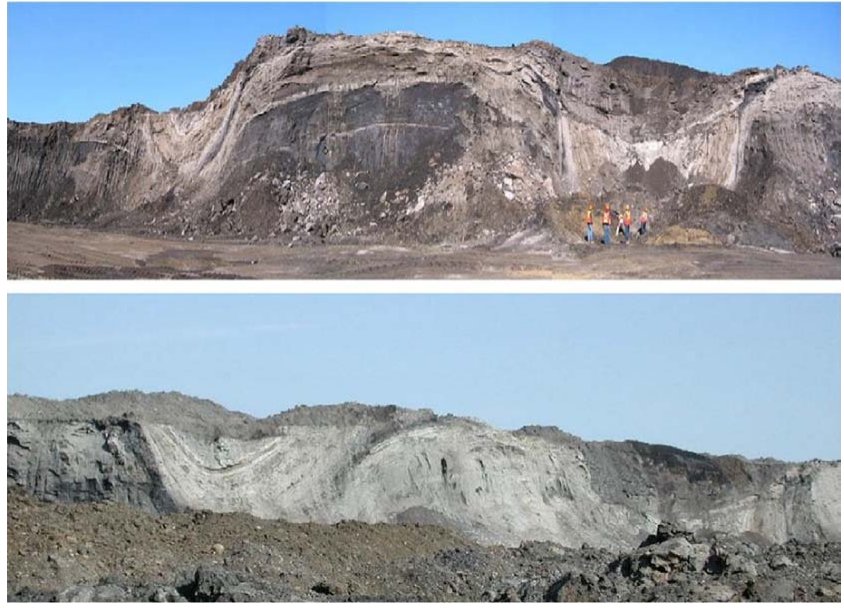

Figure 5. Lower McMurray sinkhole sags uncovered during mining at an oil sand mine. The bench height is $10-15 \mathrm{~m}$

likely seeping into the aquatic environment was 11 million 1/d. A Royal Society of Canada Expert Panel (Gosselin et al., 2010) examined this calculation and suggested that the amount was not that great, but information to make a better estimate was not available. The oil sand companies attempt to keep tailings seepage rates low with monitoring systems and collection wells and ditches built into tailings containment structures. EPLs are different from tailings ponds in that they are below natural ground levels and are not contained by tailings dams; therefore, their seepage generally would be into underlying strata. Given the complexity of the underlying geologic formations, seepage amounts and flow paths from proposed EPLs would be difficult to predict, and no publicly available study has been made to quantify such seepage. The authors' results here are not site specific. They simply evaluate a potential pond bottom flux, for an extreme set of boundary conditions at a hypothetical EPL.
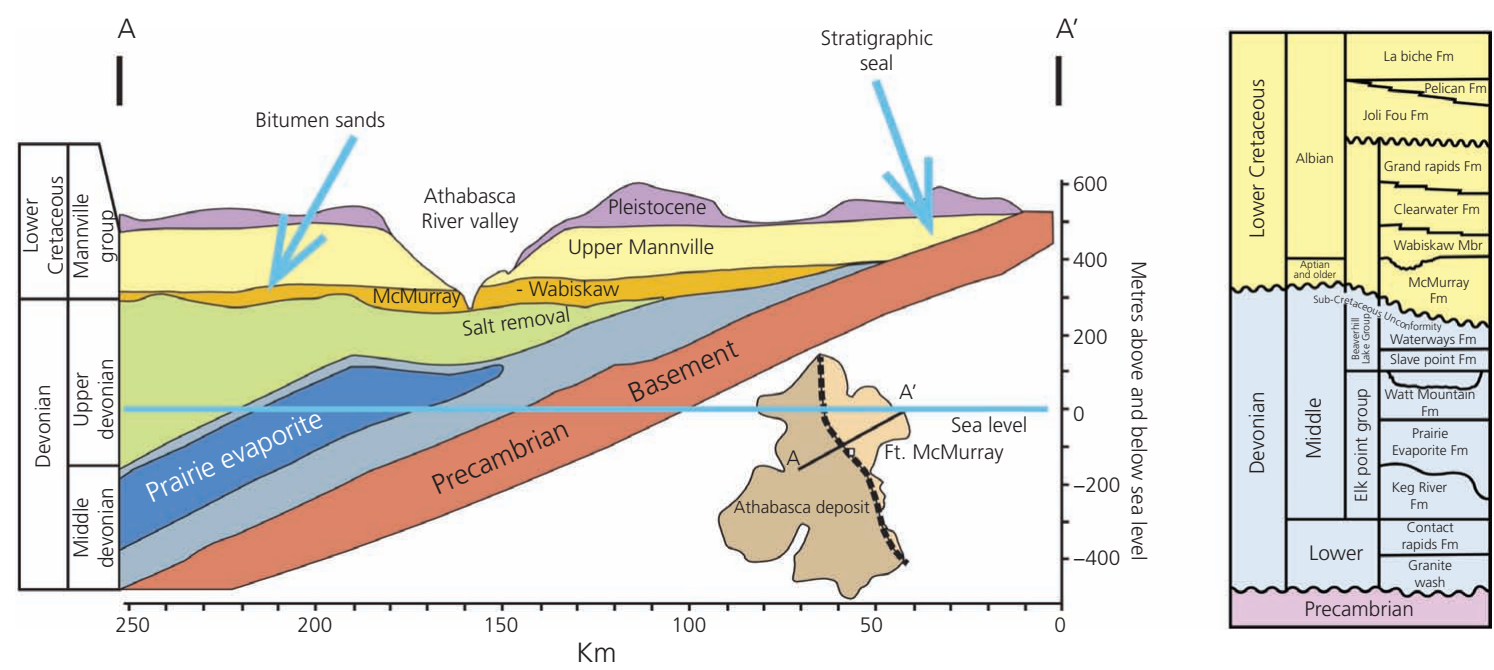

Figure 4. Typical cross-section of the oil sand deposits near the surface mining operations (after Broughton (2013)) 
The Alberta government has made it a priority that each operator must employ tailings technology and a management plan in a manner in which all fine tailings will either be reclaimed or be in a reclaimable state within 10 years of the end of mining (Alberta Government, 2015b). Several tailings dewatering technologies and deposition plans have been introduced in order to reach the reclamation goals. Many rely on self-weight consolidation in an EPL where tailings are deposited in a mined-out pit underlain by the bottom of the mine. A typical design basis assumes that a tailings deposit will seal itself at the bottom due to self-weight consolidation and that bottom seepage would be practically small and negligible. A few articles have described a technique to seal a tailings pond bottom by using fine tailings material (Clark and Moyer, 1974; Soderberg and Busch, 1977); however, little research has been performed to evaluate this bottom seal assumption. For EPLs that do not contain fine tailings, there is no seal beyond the natural geologic formations and their bottom seepage would be greater. Seepage of tailings water into an underlying permeable aquifer and flow to surface waters can result in detrimental environmental impacts. The rate and amount of bottom seepage and potential flow paths therefore should be evaluated as part of the design process. Recent research published by Environment Canada has provided a strong indication that oil sand tailings water is seeping into the Athabasca River (Frank et al., 2014).

\section{Modelling bottom seepage}

Jeeravipoolvarn et al. (2014) examined the assumption that the tailings will consolidate at the bottom of a tailings pond or EPL and seal against possible leakage. To simulate a tailings pond underlain by a permeable stratum, a $2 \mathrm{~m}$ high standpipe test with a bottom drainage layer was performed on typical oil sand fine tailings. The results from this standpipe test, which was conducted for up to 2 years, were used to validate a finite strain consolidation model. The model used compressibility and hydraulic conductivity relationships obtained from a large strain consolidation test on the fine tailings material. It was found that the model was capable to capture this behaviour in the standpipe qualitatively. The model was then used to investigate the potential seepage through the bottom of tailings deposits at a commercial scale. The downward seepage rates and the downward seepage volumes for commercial-scale tailings ponds containing this type of tailings for three different depths of tailings ponds were compared.

Hypothetical commercial-scale tailings ponds with depths of 25 , 50 and $100 \mathrm{~m}$ were selected to assess for potential downward seepage for the oil sand fine tailings. It is assumed that the ponds or EPLs are filled instantaneously and that the bottom drainage is a free-draining boundary into underlying strata with ultimate bottom pore water pressure equal to the pond water surface hydrostatic pressure. Figure 6 shows the predicted bottom seepage flux in terms of cubic metres of tailings water per square metre of pond bottom per year for the oil sand fine tailings for various times up to 50 years. Although the bottom seepage flux appears small, at 25 years, it is $0.02 \mathrm{~m} /\left(\mathrm{m}^{2}\right.$ year $)$, which for a $10 \mathrm{~km}^{2}$ area pond would be a seepage rate of $200000 \mathrm{~m}^{3} /$ year.

Figure 7 shows bottom seepage flux and per cent consolidation near the bottom for the tailings. The bottom seepage rate is directly related to the per cent consolidation near the bottom of the deposit, both exponentially changing with time. The consolidation causes reductions in void ratio and hydraulic conductivity. The hydraulic conductivity of the material at this location is reduced rapidly from the initial value of about $10^{-7} \mathrm{~m} / \mathrm{s}$ to the final value of about $10^{-10} \mathrm{~m} / \mathrm{s}$, lower than the value required for typical clay liners for landfills. Although the hydraulic conductivity is small, the bottom water pressure is higher and the area of an EPL is much larger than that of a landfill, resulting in much greater seepage volumes.

With the possibility of sinkholes, additional numerical analysis was performed to simulate the consolidation behaviour of tailings deposited on a sinkhole location. In this simulation, the sinkhole was assumed to have a constant water table at the bottom of the tailings and the tailings pond was assumed to have zero water

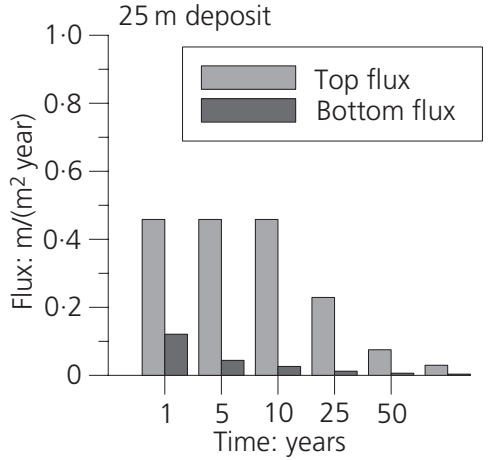

Total top drainage $=92.6 \%$ Total bottom drainage $=7 \cdot 4 \%$

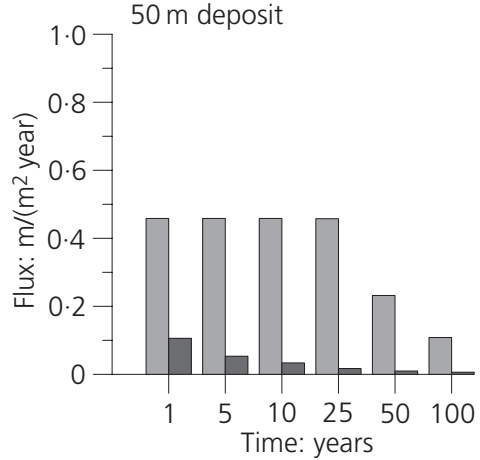

Total top drainage $=95.4 \%$ Total bottom drainage $=4.6 \%$

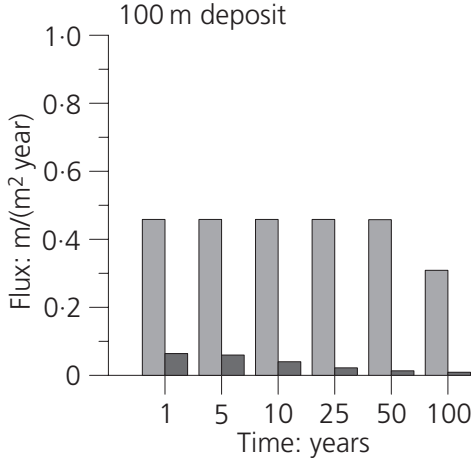

Total top drainage $=97 \cdot 3 \%$ Total bottom drainage $=2 \cdot 7 \%$

Figure 6. Drainage flux prediction for double-drainage boundary condition (after Jeeravipoolvarn et al. (2014)) 


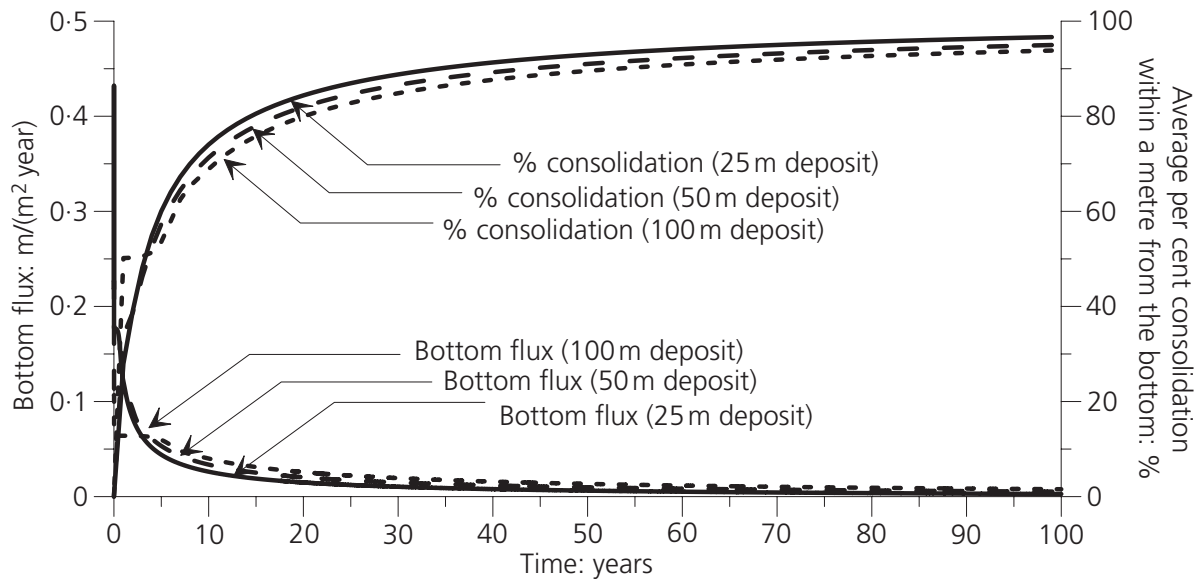

Figure 7. Bottom seepage flux and consolidation for double-drainage boundary condition (after Jeeravipoolvarn et al. (2014))

cap. The analysis was performed for three tailings pond depths of 25, 50 and $100 \mathrm{~m}$, identical to the simulations in Figure 6. A hydrogeologic boundary condition proposed by Schiffman et al. (1994) was used to simulate the sinkhole.

Analysis results are shown in Figure 8. Compared to the doubledrainage simulation in Figure 6 , for a $50 \mathrm{~m}$ deep pond, the sinkhole simulation indicated that both top and bottom fluxes from the sinkhole simulation were larger at the beginning of the analysis; but they decreased rapidly and became smaller than the values for the double-drainage simulation as time progressed. Similar trends were observed for 25 and $100 \mathrm{~m}$ deep ponds. The larger excess pore water pressure due to the base leakage boundary condition caused a rapid consolidation of tailings in this location. The greater excess pore water pressure also caused greater void ratio reduction at the base and thus a lower hydraulic conductivity at the base with a value of about $10^{-11} \mathrm{~m} / \mathrm{s}-\mathrm{a}$ magnitude lower than that for the double-drainage case. This lowhydraulic-conductivity material results in the eventual lower bottom flux.

The hypothetical simulation suggested that the presence of a sinkhole could cause a rapid consolidation of the material at the sinkhole location and result in a sealing effect. However, before the sealing can take place, the material has to consolidate and some downward seepage into the ground is expected. In addition, the leakage boundary condition due to sinkhole would also cause a continuing downward seepage even after the end of consolidation.

\section{Monitoring EPLs}

As EPLs are permanent features of the final landscape, they should be monitored until they become steady state. The planning, designing, constructing, monitoring and certifying of oil

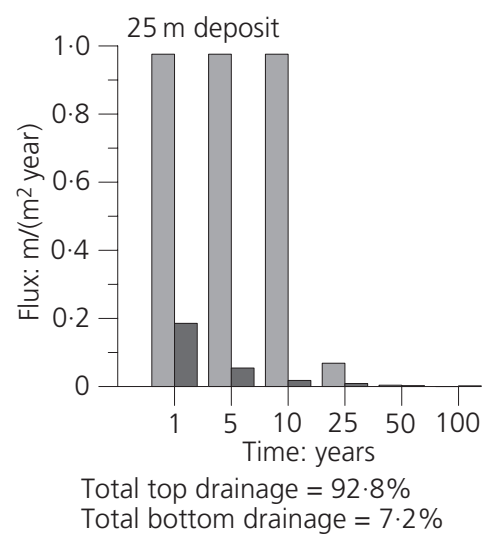

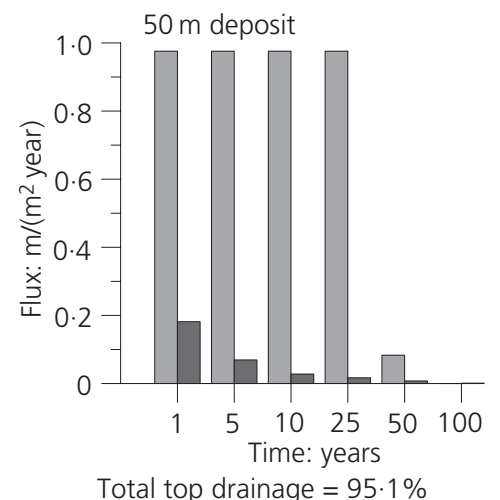

Total bottom

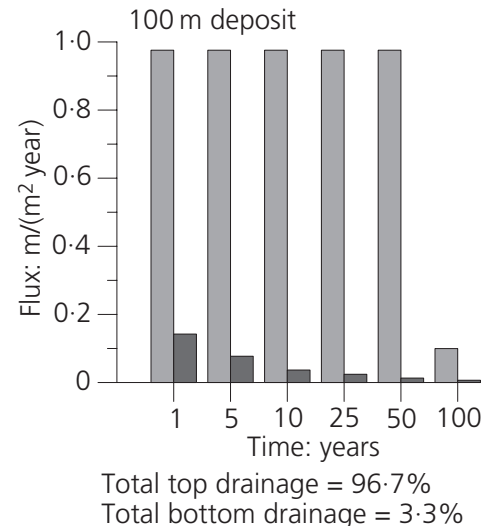

Total bottom drainage $=3 \cdot 3 \%$

Top flux

Bottom flux

Figure 8. Drainage flux prediction for hydrogeologic boundary condition 
sand EPLs is expected to be a multidecade process. Each case is expected to be somewhat unique in this regard, but it is not unreasonable to expect that perhaps 100 years will be required from the initial planning of an oil sand mine to the certification of an EPL at that mine. This extended timeframe brings with it many project management challenges that will need to be managed to ensure a successful outcome for the EPL (CEMA, 2012e). This would require that monitoring of the performance of an EPL may continue for 100 years. Figure 1 shows a typical EPL after completion. Monitoring stations and monitoring boats measuring the performance of the fine tailings with depth as well as shoreline, inlet and outlet performance monitoring would be typical. As horizontal well technology has been greatly developed in Alberta, it would be possible to install horizontal wells at various depths in the underlying formations to measure the direction of groundwater flow and sample the groundwater for changes in chemistry.

\section{Conclusions}

EPLs are common at open-pit mines around the world. Precious metal mines, iron mines, coal mines and uranium mines have EPLs as part of their mine closure plans. Oil sand mines are different with their planned EPLs being considerably larger, the area averaging about $4 \mathrm{~km}^{2}$ and reaching up to about $15 \mathrm{~km}^{2}$.

Alberta's Ministry of Sustainable Resource Development stated the following objective: '... end pit lakes have to be designed to fit the future landscape ... and to be a surface feature that can be used by the general public and any other land users, in a safe and appropriate ... manner' (CEMA, 2012a: p. 13). It is proposed that EPLs can meet this objective while providing permanent containment of fine tailings solids under a freshwater cap. The permanent placement of fine tailings solids in EPLs is approved for many oil sand mines by the AER, subject to demonstration. This demonstration has not been completed yet, but is in progress at Syncrude.

Seepage of the contained tailings water through the bottom of an EPL into the groundwater regime and eventually into surface waters is controlled by many factors, with the underlying geology being a main influence. Sinkhole sags originating in the underlying Prairie Evaporite Formation are observed cutting the entire lower McMurray interval attached to underlying Devonian fault blocks or breccia pipes. These $20-25 \mathrm{~m}$ dia. structures have been uncovered during oil sand mining operations in the Aurora and Muskeg River mines. These structures usually extend vertically to the top of the lower McMurray interval and provide vertical channels for groundwater migration.

Modelling of fine oil sand tailings in the bottom of EPLs indicates that the fine tailings will tend to seal the bottom. Although the consolidation of fine tailings at the bottom of an EPL will tend to seal the bottom of an EPL, the very large area of a typical oil sand EPL will allow a considerable amount of seepage into the underlying permeable strata. Although the bottom seepage flux becomes small, at 25 years, it is only $0.02 \mathrm{~m} /\left(\mathrm{m}^{2}\right.$ year $)$; it would result, however, for a $10 \mathrm{~km}^{2}$ area pond in a seepage rate of $200000 \mathrm{~m}^{3} /$ year.

As the EPLs are permanent features of the final landscape, the monitoring of their performance may have to continue for 100 years and should be considered by regulators as part of future assessments, research and policy development.

\section{Acknowledgements}

The authors would like to acknowledge the support from the University of Alberta and Vivian Giang for reviewing the paper.

\section{REFERENCES}

Alberta Government (2015a) Alberta's Oil Sands - about the Resource. Alberta Government, Edmonton, AB, Canada. See http://oilsands. alberta.ca/resource.html (accessed 17/04/2015).

Alberta Government (2015b) Lower Athabasca Region - Tailings Management Framework for the Mineable Athabasca Oil Sands. Alberta Government, Edmonton, AB, Canada.

Bill S (2014) Athabasca River Low in Heavy Metals from Oil Sands. University of Alberta, Edmonton, AB, Canada.

Broughton PL (2013) Devonian salt dissolution-collapse breccias flooring the Cretaceous Athabasca oil sands deposit and development of lower McMurray Formation sinkholes, northern Alberta Basin, Western Canada. Sedimentary Geology 283: 57-82, https://oi.org/10.1016/j. sedgeo.2012.11.004.

Burkus Z, Wheler J and Pletcher S (2014) GHG Emissions from Oil Sands Tailings Ponds: Overview and Modelling Based on Fermentable Substrates - Part I: Review of the Tailings Ponds Facts and Practices. Alberta Environment and Sustainable Resource Development, Calgary, AB, Canada.

CEMA (Cumulative Environmental Management Association) (2012a) Chapter 3: experiences from non-oil sands pit lakes. End Pit Lakes Guidance Document. CEMA, Fort McMurray, AB, Canada, pp. 61-98.

CEMA (2012b) End Pit Lakes Guidance Document. CEMA, Fort McMurray, AB, Canada.

CEMA (2012c) Chapter 9: construction and operation. End Pit Lakes Guidance Document. CEMA, Fort McMurray, AB, Canada, pp. 319-360.

CEMA (2012d) Chapter 5: watersheds in the mining environment. End Pit Lakes Guidance Document. CEMA, Fort McMurray, AB, Canada, pp. 139-174.

CEMA (2012e) Chapter 7: timelines and drivers. End Pit Lakes Guidance Document. CEMA, Fort McMurray, AB, Canada, pp. 215-264.

Clark DA and Moyer JE (1974) An Evaluation of Tailings Ponds Sealants. National Environmental Research Center, US Environmental Protection Agency, Corvallis, OR, USA.

Environmental Defence (2008) The Tar Sands' Leaking Legacy, Toronto, Canada. Environmental Defence, Toronto, ON, Canada.

Environmental Protection and Enhancement Act 2000. RSA 2000, c. 12 (Supp), s. 2.

Frank RA, Roy JW, Bickerton G et al. (2014) Profiling oil sands mixtures from industrial developments and natural ground waters from source identification. Environmental Science \& Technology 48(5): 2660-2670, https://doi.org/10.1021/es500131k.

Gibson JJ, Fennell J, Birks SJ et al. (2013) Evidence of discharging saline formation water to the Athabasca River in the oil sands mining region, northern Alberta. Canadian Journal of Earth Sciences 50(12): 1244-1257, https://doi.org/10.1139/cjes-2013-0027.

Gosselin P, Hrudey S, Naeth A et al. (2010) The Royal Society of Canada Expert Panel: Environmental and Health Impacts of Canada's Oil Sands Industry. The Royal Society of Canada, Ottawa, ON, Canada. Jeeravipoolvarn S, Miller W, Scott JD and Kabwe L (2014) Modeling bottom seepage from oil sands tailings ponds. Proceedings of the 
International Oil Sands Tailings Conference, Lake Louise, AB Canada, 7-10 December, pp. 101-112.

Schiffman RL, McArthur JM and Gibson RE (1994) Consolidation of clay layers: hydrogeologic boundary conditions. Journal of Geotechnical Engineering 120(6): 1089-1093, https://doi.org/10.1061/(ASCE)07339410(1994)120:6(1089).
Soderberh RL and Busch RA (1977) Design Guide for Metal and Nonmetal Tailings Disposal. Bureau of Mines, US Department of Interior, Washington, DC, USA.

Westcott F (2007) Oil Sands End Pit Lakes: a Review to 2007. Cumulative Environmental Management Association End Pit Lakes Subgroup, Fort McMurray, AB, Canada.

\section{How can you contribute?}

To discuss this paper, please submit up to 500 words to the editor at journals@ice.org.uk. Your contribution will be forwarded to the author(s) for a reply and, if considered appropriate by the editorial board, it will be published as a discussion in a future issue of the journal. 